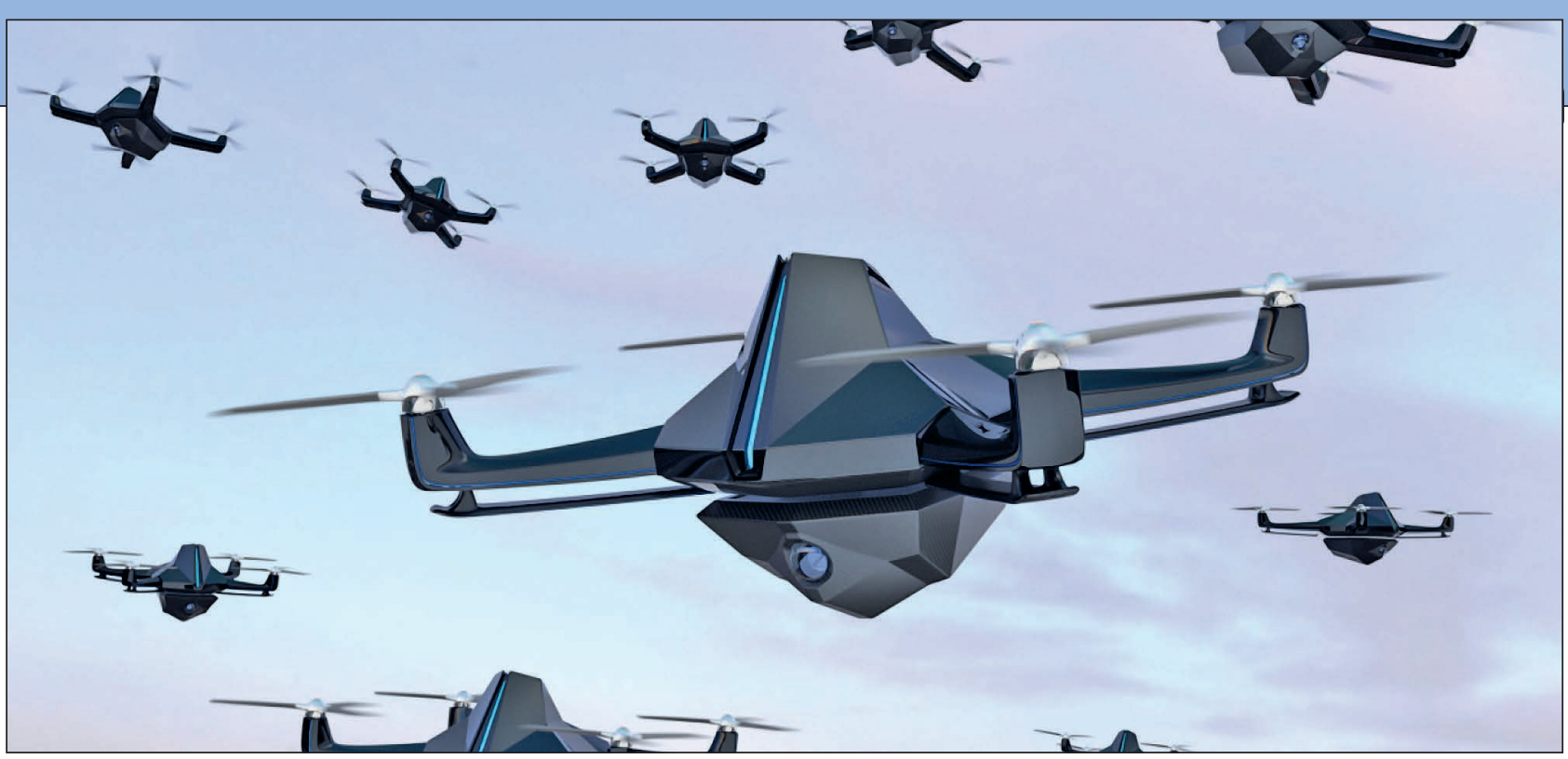

1. ábra. A drónrajok korszaka közeleg

Németh András* - Pápics Patrik ${ }^{* *}$

\title{
Mini UAV-rajok alkalmazásának lehetőségei, különös tekintettel a katonai célú
} igénybevételre trresz

\section{Bevezetés}

A repülés területén az elmúlt évszázadban végbemenő fejlődésnek köszönhetően a XXI. században már bárki megtapasztalhatja akár a biztonságos repülés, akár egyegy pilóta nélküli légijármű rendszer (UAS - Unmanned Aircraft System) tevékenységének távolról történő uralásának érzését. A pilóta nélküli légi járművek (UAV - Unmanned Aerial Vehicle) vagy közismertebb nevükön drónok kutatása - a felhasználható technológiák és technikák széles körben való hozzáférhetővé válásának köszönhetően - az elmúlt évtizedben kapott új lendületet. Az ilyen, műszaki szempontból komplex rendszerként kezelendő eszközök gyors fejlődése ugyanakkor nemcsak technikai területen indukált újabb kutatásokat, hanem azok gyakorlatban történő felhasználási lehetősége is egyre fontosabb fókuszterületé vált a polgári, kereskedelmi, vagy a közszolgálati és katonai célú alkalmazások esetén [2][3].
Az UAV-k felhasználása tekintetében ugyanakkor egy olyan új és előremutató irányzat is megjelent, amelyet a természet, rovarcsoportok megfigyelésének eredményei, közelebbről a hangyakolóniák működése, az egyedek közötti munkamegosztás ihletett. Ennek értelmezése és lemodellezése eredményeként született meg a rajtechnológia, amelynek a drónok alkalmazására gyakorolt hatásai ma még nem láthatók pontosan előre.

Vizsgálatunk alapját jelen cikkünkben az UAV-k egy szűkebb csoportja a „mini” drónok képezik, amelyek többek között az alacsonyabb költségű előállítás lehetősége miatt is alkalmasak a tömeges alkalmazásra, rajba történő szervezésre és kollektív intelligenciával való felruházásra. A kategória meghatározása során a drónkutatás és alkalmazás területén is élenjáró (egyik) ország, az Amerikai Egyesült Államok (USA) hadereje által kibocsátott stratégiai dokumentumot vettük alapul, ami előrejelzést ad az UAS-k jövőbeni katonai alkalmazására vonatkozóan [4].
ÖSSZEFOGLALÁS: A Haditechnika folyóirat már a 2019. évi 4. számában is foglalkozott a katonai robotok egyes kategóriáira jellemző fejlesztési környezet jellemzőinek elemzésével [1]. A jelen tanulmány témája - a katonai robotok rajban történő alkalmazásának vizsgálata - a jövő hadviselésének egyik meghatározó területe lesz. Elsőként a kis méretú, pilóta nélküli repülőeszközök rajban történő katonai alkalmazására kerülhet sor.

KULCSSZAVAK: robotika, rajzás, haditechnikai $\mathrm{K}+\mathrm{F}$, UAV, rajintelligencia, drónrajok irányitása, UAS csoportosítás
ABSTRACT: Already in its issue 4 of 2019, the journal Military Technology dealt with the analysis of the characteristics of the development environment of each category of military robots [1]. The subject of this study, namely exploring the use of military robots in swarm, will be one of the decisive areas of future warfare. Military application of small unmanned aerial vehicles put into action in swarms could take place first.

KEY WORDS: robotics, swarming, military technological R\&D, swarm intelligence, control of drone swarms, grouping by UAS

\footnotetext{
* Őrnagy, egyetemi docens, NKE Hadtudományi és Honvédtisztképző Kar, Elektronikai Hadviselés Tanszék. ORCID: 0000-0003-2397-189X
}

** Hadnagy, MH Légi Vezetési és Irányítás Központ. ORCID: 0000-0002-9478-3418 
Ez öt különböző kategóriába (1. táblázat) sorolja az eszközöket a pár centiméteres harcászati szinten alkalmazható egyedektől, egészen a hagyományos (pilóta által vezetett) repülőgépekkel megegyező méretű, stratégiai szinten alkalmazható drónokig. Az 1. és 2. csoportba tartozó UAV-re a miniatűr, vagy a kis méretű pilóta nélküli légi jármű (SUAV - Small Unmanned Aerial Vehicle) specifikus megnevezés használható, amelyek tömege nem haladja meg a $25 \mathrm{~kg}$-ot. Rajokban történő alkalmazás szempontjából - méretük miatt - elsődlegesen az 1. csoportba tartozó eszközök jöhetnek szóba, amelyek közös működtetése során a mozgatás és tárolás még tömeges alkalmazás esetén sem jelenthet komoly problémát. A kis méretű eszközök katonai alkalmazása dandár, illetve alacsonyabb szintű műveletek esetén lehet releváns elsősorban hírszerzési, megfigyelési és felderítési (ISR - Intelligence, Surveillance and Reconnaissance) feladatok végrehajtása során, vagy célmegjelölésre, célkövetésre (TA - Target Acquisition), illetve azonosításra [4][5].

Napjainkra már a konvencionális hadviselés részévé váltak a pilóta nélküli légi eszközök. Veszélyes feladatok végrehajtása során, alkalmazásukkal élőerő kockáztatása nélkül lehetséges a jelenlét biztosítása különböző veszélyes területeken. A stratégiai és hadászati szinten alkalmazható típusok logisztikai kiszolgálásának igénye azonban vetekszik a hagyományos, pilóta által vezetett repülőeszközökével, valamint beszerzési és fenntartási költségeik is jelentősek. Ezzel szemben az SUAV-k alacsony költségen beszerezhetők, vagy előállíthatók, felépítésük nagyságrendekkel egyszerübb, pótlásuk, illetve javításuk nagyobb darabszám esetén is hatékonyan megoldható. A fenti tulajdonságok

1. táblázat. Az Amerikai Egyesült Államok UAS csoportosítása'

\begin{tabular}{|l|c|c|c|}
\hline $\begin{array}{c}\text { UAS } \\
\text { kategória }\end{array}$ & $\begin{array}{c}\text { Maximális } \\
\text { felszálló } \\
\text { tömeg } \mathbf{( k g )}\end{array}$ & $\begin{array}{c}\text { Repülési } \\
\text { magasság } \\
\mathbf{( m )}\end{array}$ & $\begin{array}{c}\text { Repülési } \\
\mathbf{s e b e s s e ́ g ~} \\
\mathbf{( k m} / \mathbf{h})\end{array}$ \\
\hline 1. csoport & $<9$ & $<365$ & $<185$ \\
\hline 2. csoport & $9-25$ & $<1067$ & $<463$ \\
\hline 3. csoport & $<600$ & $<5490$ & $<463$ \\
\hline 4. csoport & $>600$ & $<5490$ & $>463$ \\
\hline 5. csoport & $>600$ & $>5490$ & $>463$ \\
\hline
\end{tabular}

teszik lehetővé tömeges alkalmazásukat egy-egy bevetés eredményessége érdekében, amelynek végrehajtása során az egyes „egyedek"2 rajba szervezve, a kollektív intelligencia képességével felruházva osztják meg egymás között a kapcsolódó részfeladatokat. Egy-egy drón elvesztése nem jelenti automatikusan a küldetés kudarcát, mivel a topológia, illetve a megváltozott erőforrások függvényében, akár az egyes résztevékenységek újra-priorizálásával a raj képes a feladatrendszer átkonfigurálására. Természetesen az alkalmazások tervezése során célszerű fokozott figyelmet szentelni az egyedek méretéből fakadó fizikai korlátoknak, így közepes bevetési távolság és repülési magasság mellett többek között megtévesztésre, zavarásra, felderítésre, területfelügyeletre, objektumvédelemre használhatók. Amennyiben biztosítjuk az eszközök akkumulátorai autonóm töltésének feltételeit, illetve a kieső egyedek folyamatos utánpótlását, elhúzódó műveletek során akár permanens jelenlét biztosítása is lehetséges.

A világon jelenleg számos kutatás, illetve kísérlet zajlik a rajtechnológia alkalmazásával kapcsolatban, az irányítási rendszerek, vezérlési algoritmusok és eljárások tesztelése érdekében. Ezek közül néhány ismertebb projekt paramétereit tartalmazza a 2. táblázat.

\section{A RAJINTELligenCia alaPJAI}

A XX. század második felében a rovartársadalmak (hangyák, méhek, termeszek) viselkedésének megfigyelését célzó kutatások során a rajba történő szerveződést, kooperatív viselkedést és a munkamegosztást vizsgálták, amely alapján megállapították, hogy a hierarchikus rendszerben az egyszerű feladatokat ellátó egyedek alkotják a kolóniák legnagyobb közösségét [6]. Az ezen megfigyelések alapján megalkotott raj-intelligencia (SI - Swarm Intelligence) kifejezés egy decentralizált, önszerveződő, kollektív viselkedési formát jelölt, ahol a rendszer elemei alacsonyrendű botok ${ }^{9}$, amik csupán lokálisan képesek kommunikálni társaikkal és a környezettel. Ezek a botok egyszerű szabályok alapján tevékenykednek, és a központosított irányítási struktúra hiánya ellenére - ami meghatározná az egyének számára viselkedésüket - a végbemenő véletlenszerű interakciók következtében olyan intelligensnek mondható globális viselkedési rendszert alkotnak, ami az egyén számára ismeretlen. Ezek alapján a raj tevékenységét az azt alkotó elemek képességei nem korlátozzák,

2. táblázat. Hazai és nemzetközi projektek paraméterei ${ }^{3}$

\begin{tabular}{|l|c|c|c|c|c|c|c|}
\hline \multicolumn{1}{|c|}{ Projekt } & $\begin{array}{c}\text { Egyedszám } \\
(\mathbf{d b})\end{array}$ & UAV-típus & $\begin{array}{c}\text { Autonómia } \\
\text { szintje }\end{array}$ & $\begin{array}{c}\text { Müködési } \\
\text { környezet }\end{array}$ & $\begin{array}{c}\text { Szárny- } \\
\text { típus }\end{array}$ & $\begin{array}{c}\text { Interakti- } \\
\text { vitás }\end{array}$ & $\begin{array}{c}\text { Szinkronizált } \\
\text { repülés }\end{array}$ \\
\hline LOCUST & 9 & Coyote4 & magas & kültér & merev & igen & igen \\
\hline Perdix & 103 & Perdix5 & magas & kültér & merev & igen & igen \\
\hline Intel & 1218 & $\begin{array}{c}\text { Shooting } \\
\text { Star6 }\end{array}$ & közepes & kültér & forgó & igen & igen \\
\hline EHang & 1000 & $\begin{array}{c}\text { Ghostdrone } \\
2.07\end{array}$ & közepes & kültér & forgó & igen \\
\hline ELTE & 10 & Nincs adat & magas & kültér & forgó & igen & igen \\
\hline Zürich & 3 & Nincs adat & közepes & beltér & forgó & igen & igen \\
\hline Massachusetts & 16 & Szimuláción & magas & virtuális tér & forgó & igen & igen \\
\hline Kalifornia & 49 & $\begin{array}{c}\text { Crazyflie } \\
2.08\end{array}$ & közepes & beltér & forgó & igen & igen \\
\hline
\end{tabular}


hanem azoknál sokkal többre képes [7][8][9]. A rovarok viselkedésén alapuló önszerveződési képességet az úgynevezett stigmergia elve írja le, amelynek lényege, hogy az egyedek tevékenységükről nyomokat hagynak az őket követőknek, ami alapján azok folytatni tudják a megkezdett munkát, lehetővé téve olyan komplex feladatok végrehajtását, amelyek messze meghaladják az egyedek képességét. Ez a működés egy csaknem teljesen szisztematikus decentralizált tevékenységmintázatot eredményez.

A természetes rajintelligencia mesterséges környezetbe történő adaptációjának elősegítése érdekében hét alapelvet fogalmaztak meg [10][11]. Az autonómia elve szerint minden egyednek önáló tudattal kell rendelkeznie és ennek megfelelően saját feladatait nem utasításokat követve, hanem saját döntései alapján kell koordinálnia, az önszerveződést és decentralizációt támogatva. A munkamegosztás szempontjából fontos, hogy mindig adott szituációnak megfelelően, belátása szerint cselekedjen. A tudatosság elve alapján minden tagnak tisztában kell lennie lokális környezetével, az abban elhelyezkedő társai és saját képességeivel. Az egyed számára a távolabbi környezet (magasabb szint) ismerete nem szükséges, mert a többiek iránymutatásait (nyomait) követve el tud jutni oda, ha feladata úgy kívánja. A szolidaritás elve szerint minden botnak önzetlenül kell együttműködnie a többiekkel, és amint egy feladatot végrehajtott, autonóm módon új teendőt kell magának keresnie, figyelembe véve akkori pozícióját. Ezáltal biztosítható az erőforrások optimális kihasználása, ami magasabb szintű produktivitást eredményez. Az erők védelmének elve alapján az erőforrások nem koncentrálhatók, területileg minél jobban el kell osztani azokat, ezáltal csökkentve egy nagyobb arányú állományvesztés esélyét, például egy esetleges támadás esetén. Az elosztást úgy kell megvalósítani, hogy adott körülmények között a tagok a lehető legnagyobb védelemmel rendelkezzenek a környezetükben zajló változásokkal szemben. A stabilitás elve kimondja, hogy az állomány nem változtathat viselkedési tendenciáin minden alkalommal, amikor környezete megváltozik, mivel kiterjedt populációk esetén megvan a lehetőség arra, hogy ugyanazt a közösséget egyszerre több behatás is érje, és az ezek alapján, egymástól függetlenül megváltozott szervező elvek káoszt eredményeznének a rendszer működésében. A flexibilitás elve szerint a rendszernek öngyógyítónak kell lennie, azaz a megsemmisült, sérült, vagy más okból feladatát ellátni nem képes tagok által megkezdett munkát átveszik más egyedek, így csökkentve kiesésük negatív hatásait. Így a közösség az esetleges veszteségekkel szemben jó ellenállóképességgel rendelkezik, mert rugalmasan tud reagálni a környezet változásaira. A bővithetőség elve alapján a rendszernek biztosítania kell a tagok számára egy feladat végrehajtása során az erőforrások kiegészítésének lehetőségét. Ez úgy befolyásolja a rendszer működését, hogy a folyamatos feladatvégrehajtás közben, a megnövekedett egyedszám miatt a botok gyakrabban és gyorsabban találkoznak egymással, amely közben információcserére is sűrübben kerül sor.

A mesterséges rajintelligenciák kialakításának fő problematikája, hogy nem lehet leprogramozni egy adott feladat végrehajtása során bekövetkező váratlan események hatását, illetve az azokra adandó válaszokat, az egyedeknek önállóan kell reagálniuk, és a rendszer működése szempontjából optimális döntést hozniuk. Erre a számítástechnikában a metaheurisztika matematikai eljárás jelenthet kielégítő megoldást, ami hiányos információk és korlátozott számítási kapacitás esetén is képes optimalizálni az éppen zajló folyamatokat. Erre az egyik legszemléletesebb példa a hangyatelep optimalizálási eljárás (ACO - Ant
Colony Optimization), aminek egyik kísérlete azon alapszik, hogy a hangyák mindig a lehető legrövidebb utat választják az élelmiszerforráshoz. A Deneubourg féle dupla híd kísérletben az egyedek kezdetben mindkét átkelőn egyenlő valószínűséggel indulnak el, de a rövidebben átkelők gyorsabban visszatérnek, egyazon időegység alatt több nyomot (feromont) hagyva. Az erősebb jelzés irányába egyre több hangya indul el, így fokozva az egyenlőtlenséget a két átkelő között egészen addig, amíg mindegyikük a rövidebb hidat nem választja [12][13]. Az ilyen, és ehhez hasonló megoldások drónrajok irányítási rendszerébe történő adaptálása teszi lehetővé, hogy azok egy adott feladat végrehajtása során, a „kollektív bölcsesség” elve alapján, erőforrásaik optimális megosztásával mindig megtalálják adott körülmények között a lehető legjobb megoldást, illetve a környezet megváltozásakor az új feltételrendszernek megfelelően módosítsák tevékenységüket.

\section{DRÓNRAJOK IRÁNYÍTÁSA}

A számítástechnika fejlődésének köszönhetően a XX. században már számos problémára születtek algoritmizálható megoldások, ugyanakkor a fentiek alapján, az ezeken az elveken működő szoftverek nem alkalmazhatók egy folyamatosan változó környezetben való rajszintű kollektív tevékenység hatékony irányítására, koordinálására. A megoldást a rajt alkotó egyedek önállóságának, autonómia szintjének növelése, valamint a köztük való információcsere hatékonyságának fokozása és teljes automatizálása jelenti.

Az autonóm rendszerek általános kategorizálása során, a 2000-es években olyan osztályozási metódust használtak fel, amely három szempont alapján állapítja meg annak önállóságát. Ezek az ember-robot interakció (HRI - HumanRobot Interaction), a küldetés összetettsége (MC - Mission Complexity) és a környezeti nehézség (ED - Environmental Difficulty) [14][15]. Az értékelést követően kialakul egy 1 és 10 közötti skála, amelyen a legalacsonyabb autonómiaszintet a 1-es érték jelenti, ami 100\% HRI indexet, azaz ember által történő távirányítást jelent. A 10-es értékhez 0\%-os HRI tartozik, ez jelenti a maximális önállóságot. A két szélsőérték között az autonómia szint növekedésével $M C$ és ED értékei is emelkednek. A tíz autonómia szint jelentése a következő [14][15]:

1. Távirányítású eszköz;

2. Távirányítású eszköz, saját állapot-paraméterek monitorozása mellett;

3. Előre tervezett küldetés-végrehajtás kijelölt útvonal alapján;

4. A fedélzeti szenzorok adatainak lokális feldolgozása, a környezeti formák érzékelése;

5. Egyszerű akadályészlelés és -elkerülés valós idejű útvonal tervezésével;

6. Komplex akadályészlelés és -elkerülés a terep részletes kiértékelésével;

7. Mozgó tárgyfelismerés és nyomon követés, fedélzeti szenzor információk adatfúziója;

8. Más egyedekkel való együttműködés és valós idejű adatfúzió külső forrásokból;

9. Emberi szintű együttműködés rossz időjárási és környezeti hatások mellett is;

10. Teljesen autonóm rendszer az embernél is jobb teljesítményszinttel.

Komplex, dinamikusan változó (több szereplős) környezetben való feladatvégrehajtáshoz tehát legalább 7-es, míg valós együttműködésen és feladatmegosztáson alapuló műveletek során legalább 8-as szintű autonómiára van szükség. 


\section{A RAJ EGYEDEINEK VEZÉRLÉSI KOMPONENSEI}

A kollektivitást biztosító szoftverkomponens mellett a raj egyedeinek vezérlése is kiemelt figyelmet érdemel. Ennek komponenseit az egyik legnépszerủbb forgószárnyas konstrukció, a kvadrokopter példáján keresztül mutatjuk be. Dinamika szempontjából az ilyen eszközök egy könynyűszerkezetes merevítő vázzal, illetve négy, egymástól függetlenül vezérelhető, párhuzamos fixtengelyű motorral és a hozzájuk rögzített, szomszédonként ellenkező irányba (átlósan megegyező irányba) hajtott forgószárnyakkal rendelkeznek.

A motorok összehangolt vezérlésével öt alapvető komponensből (2. ábra) felépülő komplex mozgásformák hozhatók létre. Lebegés, vagy más néven függeszkedés során a négy rotor a gravitáció leküzdéséhez szükséges, azonos szögsebességgel forog (külső behatás, légmozgás nélküli esetben), miközben térbeli pozíciója és orientációja változatlan. Vertikális, azaz függőleges mozgást érhetünk el, ha minden rotor sebességét azonos mértékben növeljük (emelkedés), vagy csökkentjük (ereszkedés). Gördülő mozgás esetén oldalanként (jobb, bal) eltérő irányban, arányosan változtatjuk a rotorok szögsebességét, így a drón a vízszintes síkban oldalirányú mozgást végez, miközben magassága változatlan marad. Döntő mozgásról akkor beszélünk, ha az első és hátsó rotorok szögsebességét változtatjuk arányosan eltérő irányban, ekkor az eszköz a vízszintes síkban előre, vagy hátra halad. Forduló mozgást úgy tudunk elérni, ha az egyik átlóban lévő rotorok szögsebességét azonos mértékben növeljük, míg a másik átlóban lévőket azonos mértékben csökkentjük. Ennek hatására a drón a függőleges tengelye körül valamelyik irányban elfordul, miközben térbeli pozíciója változatlan marad [16].

A különböző mozgások precíz kivitelezésért, a rotorok fordulatszámának pontos beállításáért, összességében az eszközök levegőben történő tevékenységének vezérléséért a robotpilóta (AP - Automatic Pilot) felelős. A drónok megfelelő, stabil működéséhez az alkalmazási környezet minél alaposabb ismeretére, az abban bekövetkező változások lehető leggyorsabb érzékelésére és lereagálására van szükség. Az információk beszerzése a drónok fedélzetén elhelyezett komplex szenzorrendszer segítségével történik. E finom műszerek egysége a mozgások stabilitásának és a navigáció feltételeinek biztosítása érdekében tartalmazhat az eszköz tömegközéppontjában elhelyezett gyorsulásmérőket, amelyek a három tengely irányában történő elmozdulások sebeségváltozását mérik, nyomásmérőt, amely a magasságváltozással összefüggő adatokat szolgáltat, valamint sebességmérőt, digitális iránytüt, illetve egy, a műholdas helymeghatározó rendszer (GNSS - Global Navigation Satellite System) jeleinek vételére alkalmas vevőt, ami az eszköz pillanatnyi térbeli helyzetére vonatkozó paramétereket szolgáltatja [17].

Az UAV-k távvezérlési funkcióinak, valamint az alkalmazással összefüggő információk (fedélzeti kamerák képei, telemetriai adatok, különböző szenzorok által szolgáltatott adatok) földi vezérlőállomás (GS - Ground Station, vagy CS - Control Station) felé történő valós idejű továbbításának megvalósítása érdekében biztonságos, az interferenciáknak ellenálló, nagy megbízhatóságú kommunikációs

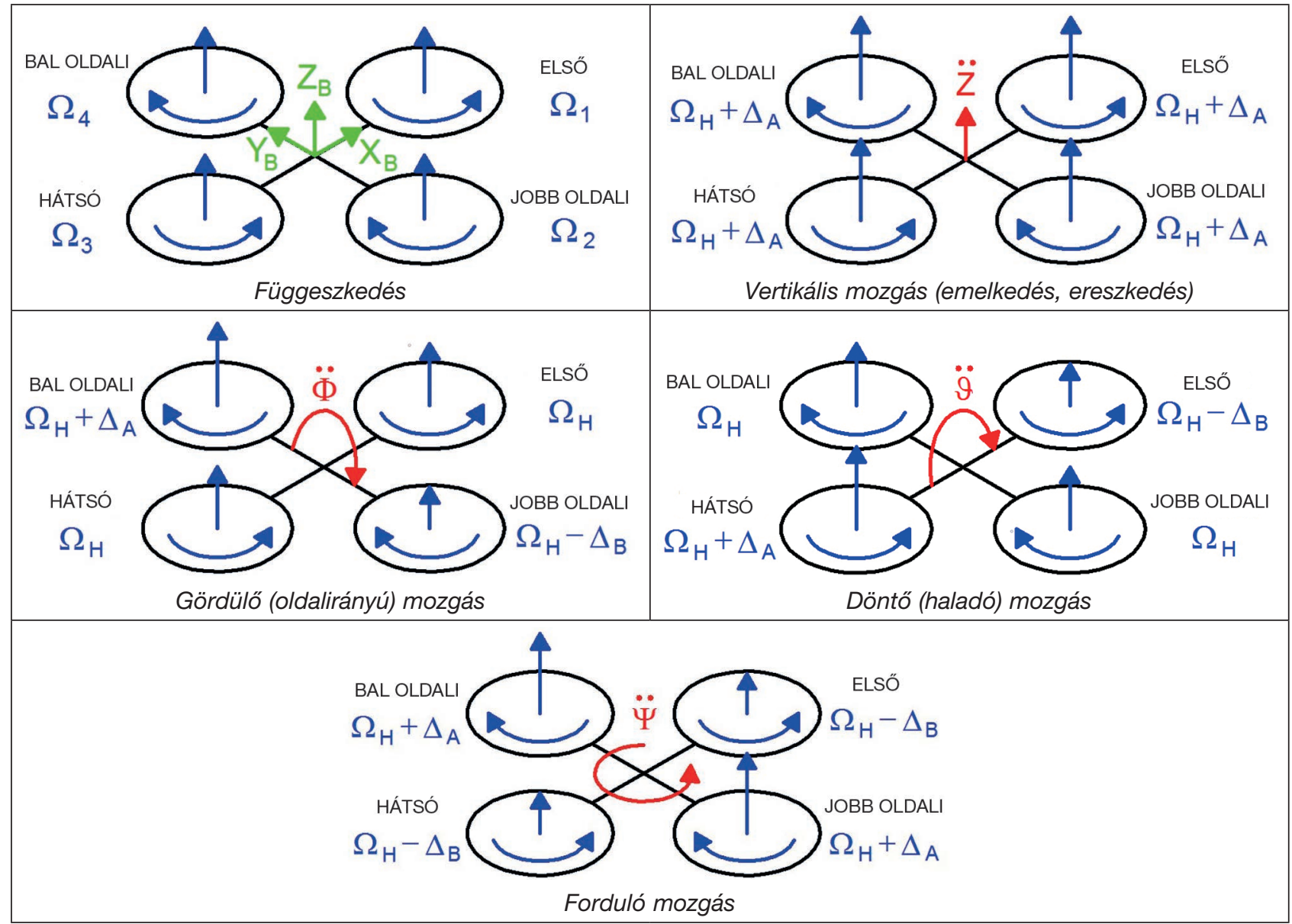

2. ábra. Négyrotoros multikopter alapmozgásai ${ }^{10}$

$18 \rightarrow$ HADITECHNIKA LIII. évf. - 2019/5 
csatorná(k) biztosítására van szükség. Ez a második generációs távvezérlési és kommunikációs megoldások esetén többnyire az ipari, tudományos és orvosi célokra szabadon felhasználható sávban (ISM - Industrial, Scientific and Medical) valósul meg a 2,4 vagy $5 \mathrm{GHz}$-es csatornákon, míg a harmadik generációs modulok már a cellás mobilkommunikációs rendszerek (4G, 5G) szabványai által kínált alacsony késleltetési idejü, nagy adatsebességű csatornákat használják fel erre a célra [18]. Ugyanakkor rajban történő alkalmazás esetén, az egyedek közötti közvetlen információcsere céljából a fentitől független, lehetőleg frekvenciában és protokollokban is jól elkülönülő pont-multipont (levegő-levegő) kapcsolatok egyidejü biztosítására képes megoldásokra, például MIMO (Multiple Input Multiple Output) antennákat [19] alkalmazó kommunikációs rendszerekre van szükség, a kollektív feladatvégrehajtást elősegítő „nyomok” (pl. a környezet, vagy a feladat pillanatnyi állapotára jellemző paraméterek) közösség tagjaival történő valós idejű megosztása érdekében.

(Folytatjuk)

\section{IRODALOMJEGYZÉK}

[1] Dr. Németh András, Dr. Hegedűs Ernő, Wippelhauser András, Simó Réka. „A katonai alkalmazású terepi autonóm járművek fejlesztésének egyes kérdései I-II. rész." Haditechnika 53, 4.-5. sz. (2019): pp. 11-16. https://doi.org/10.23713/HT.53.4.02 (I.);

[2] Németh András. „UAV-k alkalmazása a közfeladatok ellátása során I.", Hadmérnök 13, 2.sz (2018): pp. 37-60. Letöltve: 2019.07.18. http://www.hadmernok.hu/182_04_nemeth.pdf;

[3] Németh András. UAV-k alkalmazása a közfeladatok ellátása során II., Hadmérnök 13, 3. sz. (2018): pp. 68-86. Letöltve: 2019.07.18. http://www.hadmernok. hu/183_06_nemeth.pdf, Letöltve: 2018.11.12.;

[4] „Eyes of the Army: U.S. Army Roadmap for Unmanned Aircraft Systems 2010-2035," United States. Department of the Army, p.12. Letöltve: 2019.07.18. https://www.hsdl.org/?view\&did=705357;

[5] „Defense Spending by Country." globalfirepower. com Letöltve: 2019.07.18.

https://www.globalfirepower.com/defense-spendingbudget.asp;

[6] „Definition of swarm in English.” oxforddictionaries. com Letöltve: 2019.07.18. https://en.oxforddictionaries.com/definition/swarm;

[7] Beni G., Wang J. (1993) "Swarm Intelligence in Cellular Robotic Systems." In: Dario P., Sandini G., Aebischer P. (eds) Robots and Biological Systems: Towards a New Bionics?. NATO ASI Series (Series F: Computer and Systems Sciences), vol 102. Springer, Berlin, Heidelberg: 1993 https://doi.org/10.1007/978-3-642-58069-7_38;

[8] Beni G. (2005) From Swarm Intelligence to Swarm Robotics. In: Șahin E., Spears W.M. (eds) Swarm Robotics. SR 2004. Lecture Notes in Computer Science, vol 3342. Springer, Berlin, Heidelberg https://doi.org/10.1007/978-3-540-30552-1_1;

[9] Fleischer, Mark. Foundations of Swarm Intelligence: From Principles to Practice, 2003. https://doi.org/10.21236/ada440801;

[10] „Cognitive algorithm in Social Insects summarized by five behavioral principles" swarmtechnology.us
Letöltve: 2019.07.18.; http://www.swarmtechnology. us/press/2016/10/15/cognitive-algorithm-in-socialinsectsummarized-in-five-behavioral-principles;

[11] „Swarm Intelligence," techferry.com Letöltve: 2019.07.18. http://www.techferry.com/ articles/swarm-intelligence.html\#;

[12] Lin-yu Tseng. Metaheuristic Methods and Their Applications, Letöltve: 2019.07.18. https://pdfs.semanticscholar.org/9d15/dc218865f035 489d0d0320042725d4a9a42a.pdf;

[13] Natalie R. Frantz. Swarm intelligence for autonomous UAV control. Thesis, 2005 Letöltve: 2019.07.18. https://calhoun.nps.edu/bitstream/ handle/10945/2152/05Jun_Frantz.pdf?sequence=1;

[14] Huang, Hui-Min. "Autonomy Levels For Unmanned Systems (ALFUS) Framework, Volume I" (2008), p. 7-13., 28. https://doi.org/10.6028/nist.sp.1011-i-2.0 ;

[15] Huang, Hui-Min, Elena Messina, and James Albus. "Autonomy Levels For Unmanned Systems (ALFUS) Framework, Volume II" (2007), pp. 17-20., https://doi.org/10.6028/nist.sp.1011-ii-1.0;

[16] Bresciani, Tommaso. Modelling, Identification and Control of a Quadrotor Helicopter, Lundi Egyetem, 2008, p. 8-11., Letöltve: 2019.07.18.

http://lup.lub.lu.se/luur/download?func=downloadFile \&recordOld=8847641\&fileOld=8859343;

[17] Veréb Nándor. „Az UAV-k fedélzetén alkalmazott szenzorok és ezek müködése," Repüléstudományi Közlemények 28, 1. szám, (2016): p. 100-104., Letöltve. 2019.07.18. http://www.repulestudomany.hu/folyoirat/2016_1/ 2016-1-09-0323_Vereb_Nandor.pdf;

[18] Hell Péter. „Drón rendszerek biztonságos kommunikációja," Köztes - Európa Társadalomtudományi Folyóirat 8, 1-2. sz. (2016): pp. 171-174., Letöltve: 2019.07.18. http://acta.bibl.u-szeged. hu/46876/1/vikek_019_020.pdf;

[19] Mikó Gyula, Németh András. „SCFDM based communication system for UAV applications" In: IEEE Radioelektronika, 2015 25th International Conference. IEEE, Pardubice, Czech Republic, 2015. pp. 222-224. https.//doi.org/10.1109/RADIOELEK.2015.7129014.

\section{JEGYZETEK}

1 Szerzői szerkesztés a [4] p. 12., 2-2 táblázat alapján

$2 \mathrm{Az}$ angolszász irodalomban használt „individual - robot” kifejezés a legcélszerübben így fordítható (Szerk.)

3 Szerzői szerkesztés.

4 Méret: $910 \times 1470 \times$ n.a. mm, maximális felszállótömeg: $5900 \mathrm{~g}$, üzemidő: $60 \mathrm{~min}$.

5 Méret: 165,1×299,72×n.a. mm, maximális felszállótömeg: 290 g, üzemidő: $20 \mathrm{~min}$.

6 Méret: $384 \times 384 \times 93$ mm, maximális felszállótömeg: $330 \mathrm{~g}$, üzemidő: $8 \mathrm{~min}$.

7 Méret: $350 \times 350 \times 195$ mm, maximális felszállótömeg: $1150 \mathrm{~g}$, üzemidő: $25 \mathrm{~min}$.

8 Méret: $92 \times 92 \times 29$ mm, maximális felszállótömeg: 42 g, üzemidő: 7 min.

9 A „bot” kifejezés a robot kifejezésből származik „egyszerűsítéssel”. Használjuk olyan szoftverekre, amelyek egyszerü automatizált feladatokat hajtanak végre meghatározott algoritmusok szerint, vagy olyan céleszközökre is, amelyek ilyen programokat futtatva végzik autonóm módon feladataikat.

10 [16] pp. 8-11. 